\title{
Pyrazolyl Pd(II) complexes containing triphenylphosphine: Synthesis and antimycobacterial activity
}

\author{
Cristiana da Silva ${ }^{a}$, Leonardo B. Ribeiro ${ }^{a}$, Caio C. Furuno ${ }^{a}$, Gislaine A. da Cunha ${ }^{a}$, Ronan F.F. de Souza ${ }^{\text {, }}$ \\ Adelino V.G. Netto ${ }^{a}, *$, Antonio E. Mauro ${ }^{a, *}$, Regina C.G. Frem ${ }^{a}$, José A. Fernandes ${ }^{b}$, Filipe A. Almeida Paz ${ }^{b}$, \\ Leonardo B. Marino ${ }^{c}$, Fernando R. Pavan ${ }^{c}$, Clarice Q.F. Leite ${ }^{c}$
}

a Departamento de Química Geral e Inorgânica, Instituto de Química de Araraquara, UNESP - Univ Estadual Paulista, P.O. Box 355, Araraquara, São Paulo 14801-970, Brazil

${ }^{\mathrm{b}}$ Department of Chemistry, CICECO, Campus Universitário de Santiago, University of Aveiro, 3810-193 Aveiro, Portugal

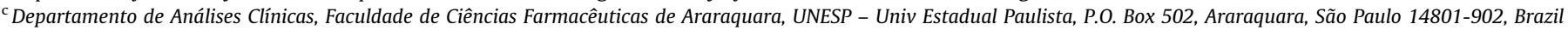

\section{A R T I C L E I N F O}

\section{Article history:}

Received 18 March 2015

Accepted 7 July 2015

Available online 13 July 2015

\section{Keywords:}

Pd(II) compounds

Triphenylphosphine

Pyrazoles

Spectroscopy

Mycobacterium tuberculosis

\begin{abstract}
A B S T R A C T
Complexes of the type trans-[ $\left.\mathrm{PdCl}_{2}(\mathrm{HL})\left(\mathrm{PPh}_{3}\right)\right]$, where $\mathrm{HL}=$ pyrazole (1); 3,5-dimethylpyrazole (2); 4-nitropyrazole (3); 4-iodopyrazole (4) and $\mathrm{PPh}_{3}=$ triphenylphosphine, were synthesized and characterized by elemental analyses, infrared and ${ }^{1} \mathrm{H}$ NMR spectroscopies. Single-crystal X-ray diffraction determination on 3.0.9 $\mathrm{CHCl}_{3}$ and $\mathbf{4}$ showed that the coordination geometry around $\mathrm{Pd}(\mathrm{II})$ is nearly square-planar with the chloro ligands in a trans configuration. In vitro antimycobacterial evaluation demonstrated that compound 4 displayed a minimum inhibitory concentration (MIC) of $7.61 \pm 2.18 \mu \mathrm{M}$, being superior to the values observed for some commonly used antituberculosis drugs and other metal-based complexes.
\end{abstract}

(c) 2015 Elsevier Ltd. All rights reserved.

\section{Introduction}

Tuberculosis (TB), an airborne infectious disease caused by Mycobacterium tuberculosis (MTB) and other mycobacteria, is still a major worldwide health threat [1]. The urgent need to discover new anti-TB agents is justified by many important reasons, mainly: (i) the outbreak of multidrug resistant (MDR) and extensively drug-resistant (XDR-TB) TB strains of M. tuberculosis; (ii) the spreading of the human immunodeficiency virus (HIV) and its deadly synergy with TB and nontubercular mycobacterial infections; (iii) the poor compliance with the complexity and toxicity of the current chemotherapeutic regimens [1-3].

In this sense, pyrazole-type heterocycles have emerged as a class of potential antimycobacterial agents [4-7]. Horrocks et al. [7] have synthesized some 3-(4-chlorophenyl)-4-substituted pyrazole derivatives which displayed not only an interesting activity against the tested strain of $M$. tuberculosis $\mathrm{H}_{37} \mathrm{Rv}$, but also exhibited remarkable antifungal activity against four pathogenic strains. Velaparthi et al. [8] have described a series of 5-tert-butyl-Npyrazol-4-yl-4,5,6,7-tetrahydrobenzo[d]isoxazole-3-carboxamide

* Corresponding authors. Tel.: +55 01633019626 (A.V.G. Netto), +55 016 33019625 (A.E. Mauro); fax: +55 01633227932 .

E-mail addresses: adelino@iq.unesp.br (A.V.G. Netto), mauro@iq.unesp.br (A.E. Mauro). derivatives as novel potent $M$. tuberculosis pantothenate synthetase inhibitors showing cytotoxicity activity $\left(\mathrm{IC}_{50}\right)$ ranging from $90 \mathrm{nM}$ to $7.13 \mu \mathrm{M}$.

The importance of pyrazole derivatives has also been accompanied by an increasing interest focused on the coordination chemistry of these heterocycles [9-11]. Particularly, metal-based compounds of pyrazoles containing phosphines as co-ligands have also received attention due to their possible use as antitumor and antimicrobial drugs $[12,13]$. Nomiya et al. [13] synthesized the complex $\left[\mathrm{Au}(\mathrm{HPz})\left(\mathrm{PPh}_{3}\right)\right]\left(\mathrm{HPz}=\right.$ pyrazole; $\mathrm{PPh}_{3}=$ triphenylphosphine $)$ which showed activities against Gram-positive bacteria (Staphylococcus aureus) and one yeast (Candida albicans). Nevertheless, studies on the antimycobacterial activity towards TB involving pyrazolyl complexes bearing phosphine ligands remain scarce in literature.

For many years, our research has been focused on the synthesis of metal compounds containing N-, P- or S-based ligands and the evaluation of their activity against tumour cell lines and $M$. tuberculosis [14-19]. Ferreira et al. have obtained the organometallic compound $[\mathrm{Pd}(\mathrm{C}-\mathrm{bzan})(\mathrm{SCN})(\mathrm{dppp})]\{$ bzan $=\mathrm{N}$-benzylideneaniline, $\mathrm{dppp}=1$, 3-bis(diphenylphosphino)propane which displayed significant antimycobacterial activity $\left(\mathrm{MIC}_{90}=5.15 \mu \mathrm{M}\right)$ [20]. Recently, we have described the synthesis of binuclear compounds of the type $\left[\mathrm{Pd}(\mu-\mathrm{L})\left(\mathrm{N}_{3}\right)\left(\mathrm{PPh}_{3}\right)\right]_{2}\{\mathrm{~L}=$ pyrazolate $(\mathrm{Pz}) ; 3,5$-dimethylpyrazolate (dmPz); 4-iodopyrazolate (IPz)\} [21]. In vitro antimycobacterial 
assays demonstrated that compound $\left[\mathrm{Pd}(\mu-\mathrm{Pz})\left(\mathrm{N}_{3}\right)\left(\mathrm{PPh}_{3}\right)\right]_{2}$ exhibited a MIC of $8.16 \mu \mathrm{M}$. This findings have prompted us to evaluate the anti-TB activity of other $\mathrm{Pd}(\mathrm{II})$ compounds bearing phosphine ligands. Inspired by the promising biological results obtained for mononuclear compounds of the type [Au(pyrazoles) $\left(\mathrm{PPh}_{3}\right)$ ] $[12,13]$ and as a part of our ongoing studies on coordination chemistry of pyrazolyl ligands [22-24], we prepared analogous $\mathrm{Pd}(\mathrm{II})$ derivatives with general formulae trans-[ $\left.\mathrm{PdCl}_{2}(\mathrm{HL})\left(\mathrm{PPh}_{3}\right)\right]$, where $\mathrm{PPh}_{3}=$ triphenylphosphine and $\mathrm{HL}$ are ligands of type pyrazole ( $\mathrm{HPz})$; 3,5-dimethylpyrazole $(\mathrm{HdmPz})$; 4-nitropyrazole $\left(\mathrm{HNO}_{2} \mathrm{Pz}\right)$ and 4-iodopyrazole ( $\mathrm{HIPz}$ ), and investigated their antimycobacterial activity against $M$. tuberculosis. The crystallographic structures of the compounds 3.0.9 $\mathrm{CHCl}_{3}$ and $\mathbf{4}$ are also described in this work.

\section{Material and methods}

\subsection{General methods}

Synthesis were performed at ambient temperature. The precursor $\left[\mathrm{PdCl}_{2}(\mathrm{MeCN})_{2}\right]$ was prepared as previously described [25]. Pyrazolyl ligands and triphenylphosphine were purchased from Sigma Aldrich or Merck. Reagents and solvents were employed without further purification.

\subsection{Synthesis}

Compounds $\left[\mathrm{PdCl}_{2}(\mathrm{HPz})\left(\mathrm{PPh}_{3}\right)\right](\mathbf{1}),\left[\mathrm{PdCl}_{2}(\mathrm{HdmPz})\left(\mathrm{PPh}_{3}\right)\right](\mathbf{2})$, $\left[\mathrm{PdCl}_{2}\left(\mathrm{HNO}_{2} \mathrm{Pz}\right)\left(\mathrm{PPh}_{3}\right)\right](3)$ and $\left[\mathrm{PdCl}_{2}(\mathrm{HIPz})\left(\mathrm{PPh}_{3}\right)\right](4)$ were prepared by adding a mixture containing $1.17 \mathrm{mmol}$ of the appropriated pyrazolyl ligand $\{79.6 \mathrm{mg}$ of $\mathrm{HPz}(\mathbf{1}), 112 \mathrm{mg}$ of $\mathrm{HdmPz}(\mathbf{2})$, $132 \mathrm{mg}$ of $\mathrm{HNO}_{2} \mathrm{Pz}$ (3) or $227 \mathrm{mg}$ of $\left.\mathrm{HIPz}(4)\right\}$ and triphenylphosphine (307 $\mathrm{mg} ; 1.17 \mathrm{mmol}$ ) in $5 \mathrm{~mL}$ of $\mathrm{CHCl}_{3}$ to an orange solution of $\left[\mathrm{PdCl}_{2}\left(\mathrm{CH}_{3} \mathrm{CN}\right)_{2}\right]$ (301 mg; $1.16 \mathrm{mmol}$ ) in $15 \mathrm{~mL}$ of $\mathrm{CHCl}_{3}$. The mixtures were stirred magnetically for $2 \mathrm{~h}$, and then the solutions were concentrated to $2 \mathrm{~mL}$ under reduced pressure. The addition of pentane $(30 \mathrm{~mL})$ resulted in the precipitation of the products 1-4, which were filtered and dried under vacuum. Yield 79-90\%.

\subsection{Physical measurements}

C, $\mathrm{H}$ and $\mathrm{N}$ analyses were performed on a Perkin Elmer 2400. Conductivities were measured with a Digimed-DM-31 conductometer using $1 \times 10^{-3} \mathrm{~mol} \mathrm{~L}^{-1}$ DMSO solutions. Infrared spectra were recorded as $\mathrm{KBr}$ pellets on a Nicolet FTIR-Impact 400 spectrophotometer in the spectral range $4000-400 \mathrm{~cm}^{-1}$ with resolution of $2 \mathrm{~cm}^{-1}$. The ${ }^{1} \mathrm{H}$ NMR spectra were obtained using $\mathrm{CDCl}_{3}$ solutions, on a Varian INOVA 500 spectrometer.

\subsection{Single-crystal X-ray diffraction studies}

Single crystals for X-ray crystallography of $\mathbf{3}$ and $\mathbf{4}$ were obtained by slow diffusion of pentane into a solution of the complexes in chloroform. X-ray diffraction data for $3.0 .9 \mathrm{CHCl}_{3}$ and 4 were collected on a Bruker X8 Kappa APEX II with a charge-coupled device (CCD) area-detector diffractometer (Mo $\mathrm{K} \alpha$ graphite-monochromated radiation, $\lambda=0.71073 \AA$ ) controlled by the APEX2 software package [26], and equipped with an Oxford Cryosystems Series 700 cryostream monitored remotely using the software interface Cryopad [27]. Images were processed using the software package sainT+ [28], and data were corrected for absorption by the multi-scan semi-empirical method implemented in SADABS [29]. The crystal structures of $\mathbf{3} .0 .9 \mathrm{CHCl}_{3}$ and 4 were solved using the Patterson synthesis algorithm implemented in SHELXS-97 [30], which allowed the immediate location of the crystallographically independent $\mathrm{Pd}^{2+}$ centers and the most of the heaviest atoms. All remaining non-hydrogen atoms were located from difference Fourier maps calculated from successive full-matrix least squares refinement cycles on $F^{2}$ using SHELXL2014 [31,32], and refined using anisotropic displacement parameters. Refinement of solvent occupancy of the chloroform molecule in 3 converged at 0.892(2), however this was fixed at 0.9.

Hydrogen atoms bound to carbon were placed at their idealized positions using appropriate HFIX instructions in SHELXL: 13 for the $\mathrm{CH}$ from chloroform and 43 for the $\mathrm{CH}$ groups of the aromatic rings. These atoms were included in subsequent refinement cycles in riding motion approximation with isotropic thermal displacements parameters $\left(U_{\text {iso }}\right)$ fixed at $1.2 \times U_{\text {eq }}$ of the parent carbon atoms. In opposition, $\mathrm{H}$ atoms bonded to nitrogen were located from difference Fourier maps and the $\mathrm{N}-\mathrm{H}$ distance and isotropic thermal displacements parameters $\left(U_{\text {iso }}\right)$ fixed at $0.88 \AA$ and $1.5 \times U_{\text {eq }}$ of the nitrogen atoms, respectively.

For compound 3.0.9 $\mathrm{CHCl}_{3}$, the last difference Fourier map synthesis showed the highest peak $\left(0.89 \mathrm{e}^{-3}\right)$ located at $1.02 \AA$ from $\mathrm{Cl} 4$, and the deepest hole $\left(-1.12 \mathrm{e}^{-3}\right)$ at $0.76 \AA$ from Pd1. For compound 4, the last difference Fourier map synthesis showed the highest peak $\left(2.59 \mathrm{e}^{-3}\right)$, and the deepest hole $\left(-3.22 \mathrm{e}^{-3}\right)$, located at 0.44 and $1.06 \AA$ from I1, respectively. Details of the crystal data and structure refinement parameters for 3.0.9 $\mathrm{CHCl}_{3}$ and 4 are summarized in Table 1.

\subsection{Antimycobacterial assays}

The anti-M. tuberculosis activity was determined by the Resazurin Microtiter Assay (REMA) [33,34]. Stock solutions of the test compounds were prepared in DMSO and diluted in

Table 1

Crystal and structure refinement data for $\left[\mathrm{PdCl}_{2}\left(\mathrm{HNO}_{2} \mathrm{Pz}\right)\left(\mathrm{PPh}_{3}\right)\right] \cdot 0.9 \mathrm{CHCl}_{3}$ (3.0.9 $\left.\mathrm{CHCl}_{3}\right)$ and $\left[\mathrm{PdCl}_{2}(\mathrm{HIPz})\left(\mathrm{PPh}_{3}\right)\right](4)$.

\begin{tabular}{|c|c|c|}
\hline & $\left(3.0 .9 \mathrm{CHCl}_{3}\right)$ & $(4)$ \\
\hline Formula & $\mathrm{C}_{21} \mathrm{H}_{18} \mathrm{Cl}_{2} \mathrm{~N}_{3} \mathrm{O}_{2}$ PPd.0.9 $\left(\mathrm{CHCl}_{3}\right)$ & $\mathrm{C}_{21} \mathrm{H}_{18} \mathrm{Cl}_{2} \mathrm{IN}_{2} \mathrm{PPd}$ \\
\hline Formula weight & 660.09 & 633.54 \\
\hline Crystal system & monoclinic & triclinic \\
\hline Space group & $P 2_{1} / n$ & $P \overline{1}$ \\
\hline$T(\mathrm{~K})$ & 150 & 150 \\
\hline$a(\AA)$ & $15.0018(8)$ & $10.2246(5)$ \\
\hline$b(\AA)$ & $9.4988(5)$ & $10.5312(5)$ \\
\hline$c(\AA)$ & $18.6528(10)$ & $12.0140(5)$ \\
\hline$\alpha\left(^{\circ}\right)$ & 90 & $102.004(2)$ \\
\hline$\beta\left(^{\circ}\right)$ & 103.784(3) & $96.708(2)$ \\
\hline$\gamma\left({ }^{\circ}\right)$ & 90 & $116.699(2)$ \\
\hline$V\left(\AA^{3}\right)$ & $2581.5(2)$ & 1097.22(19) \\
\hline$Z$ & 4 & 2 \\
\hline$D_{\text {calc }}\left(\mathrm{g} \mathrm{cm}^{-3}\right)$ & 1.698 & 1.918 \\
\hline$\theta$ range $\left(^{\circ}\right)$ & $3.6-33.1$ & $2.3-25.4$ \\
\hline$\mu(\operatorname{Mo~K\alpha })\left(\mathrm{mm}^{-1}\right)$ & 1.29 & 2.58 \\
\hline Crystal type & Yellow block & Orange block \\
\hline Crystal size (mm) & $0.15 \times 0.12 \times 0.08$ & $0.15 \times 0.12 \times 0.08$ \\
\hline Index ranges & $\begin{array}{l}-23 \leqslant h \leqslant 17 \\
-14 \leqslant k \leqslant 14 \\
-27 \leqslant l \leqslant 28\end{array}$ & $\begin{array}{l}-12 \leqslant h \leqslant 12 \\
-12 \leqslant k \leqslant 12 \\
-14 \leqslant l \leqslant 14\end{array}$ \\
\hline Reflections collected & 32371 & 52973 \\
\hline Independent reflections & $9819\left[R_{\mathrm{int}}=0.062\right]$ & $\begin{array}{l}4014 \\
{\left[R_{\text {int }}=0.0648\right]}\end{array}$ \\
\hline Completeness & $99.7 \%$ (to $\theta=30.0$ ) & $100 \%$ (to $\theta=25.4$ ) \\
\hline $\begin{array}{l}\text { Final } R \text { indices } \\
\qquad[I>2 \sigma(I)]^{\mathrm{a}, \mathrm{b}}\end{array}$ & $\begin{array}{l}R_{1}=0.047 \\
w R_{2}=0.112\end{array}$ & $\begin{array}{l}R_{1}=0.040 \\
w R_{2}=0.089\end{array}$ \\
\hline Weighting scheme ${ }^{c}$ & $\begin{array}{l}m=0.0446 \\
n=0\end{array}$ & $\begin{array}{l}m=0.183 \\
n=6.1607\end{array}$ \\
\hline $\begin{array}{l}\text { Largest diff. peak and } \\
\text { hole }\left(e \AA^{-3}\right)\end{array}$ & 0.89 and -1.12 & 2.59 and -3.22 \\
\hline \multicolumn{3}{|l|}{${ }^{\mathrm{a}} R_{1}=\sum|| F_{o}|-| F_{c}|| / \sum\left|F_{o}\right|$. } \\
\hline
\end{tabular}


Middlebrook 7H9 broth (Difco), supplemented with oleic acid, albumin, dextrose and catalase (OADC enrichment - BBL/Becton Dickinson, Sparks, MD, USA), to obtain final compound concentration ranging from 0.15 to $250 \mu \mathrm{g} \mathrm{mL}^{-1}$. The serial dilutions were performed in a Precision XS Microplate Sample Processor (Biotek ${ }^{\mathrm{TM}}$ ). The isoniazid was dissolved in distilled water, according to the manufacturers' recommendations (Difco laboratories, Detroit, MI, USA), and used as a standard drug. M. tuberculosis $\mathrm{H}_{37} \mathrm{Rv}$ ATCC 27294 was grown for 7-10 days in Middlebrook 7H9 broth supplemented with OADC, plus $0.05 \%$ Tween 80 to avoid clumps. Suspensions were prepared and their turbidities matched to the optical density of the McFarland No. 1 standard. After a further dilution of 1:25 in Middlebrook 7H9 broth supplemented with OADC, $100 \mu \mathrm{L}$ of the culture were transferred to each well of a 96well microtiter plate (NUNC), together with the test compounds. Each test was set up in triplicate. Microplates were incubated for 7 days at $37^{\circ} \mathrm{C}$, after which resazurin was added for the reading. Wells that turned from blue to pink, with the development of fluorescence, indicated growth of bacterial cells; maintenance of the blue colour indicated bacterial inhibition. The fluorescence was read $(530 \mathrm{~nm}$ excitation filter and $590 \mathrm{~nm}$ emission filter) in a SPECTRA fluor Plus (Tecan) microfluorimeter. The MIC was defined as the lowest concentration resulting in $90 \%$ inhibition of growth of M. tuberculosis. As a standard test, the MIC of isoniazid was determined on each microplate. The acceptable range of isoniazid MIC is from 0.015 to $0.05 \mu \mathrm{g} \mathrm{mL}^{-1}[34,35]$.

\section{Results and discussion}

Compound $\left[\mathrm{PdCl}_{2}(\mathrm{MeCN})_{2}\right]$ reacts with the appropriate pyrazolyl ligand (HL) and triphenylphosphine $\left(\mathrm{PPh}_{3}\right)$, in a 1:1:1 molar ratio, respectively, to yield mononuclear compounds of the type $\left[\mathrm{PdCl}_{2}(\mathrm{HL})\left(\mathrm{PPh}_{3}\right)\right]$. A general scheme which represents the strategy employed for the synthesis of the complexes is given in Scheme 1.

Complexes 1-4 are air and light stable solids soluble in DMSO and chloroform and exhibit colour that varies from light yellow to orange. The elemental analysis and molar conductivity results are given in Table 2 .
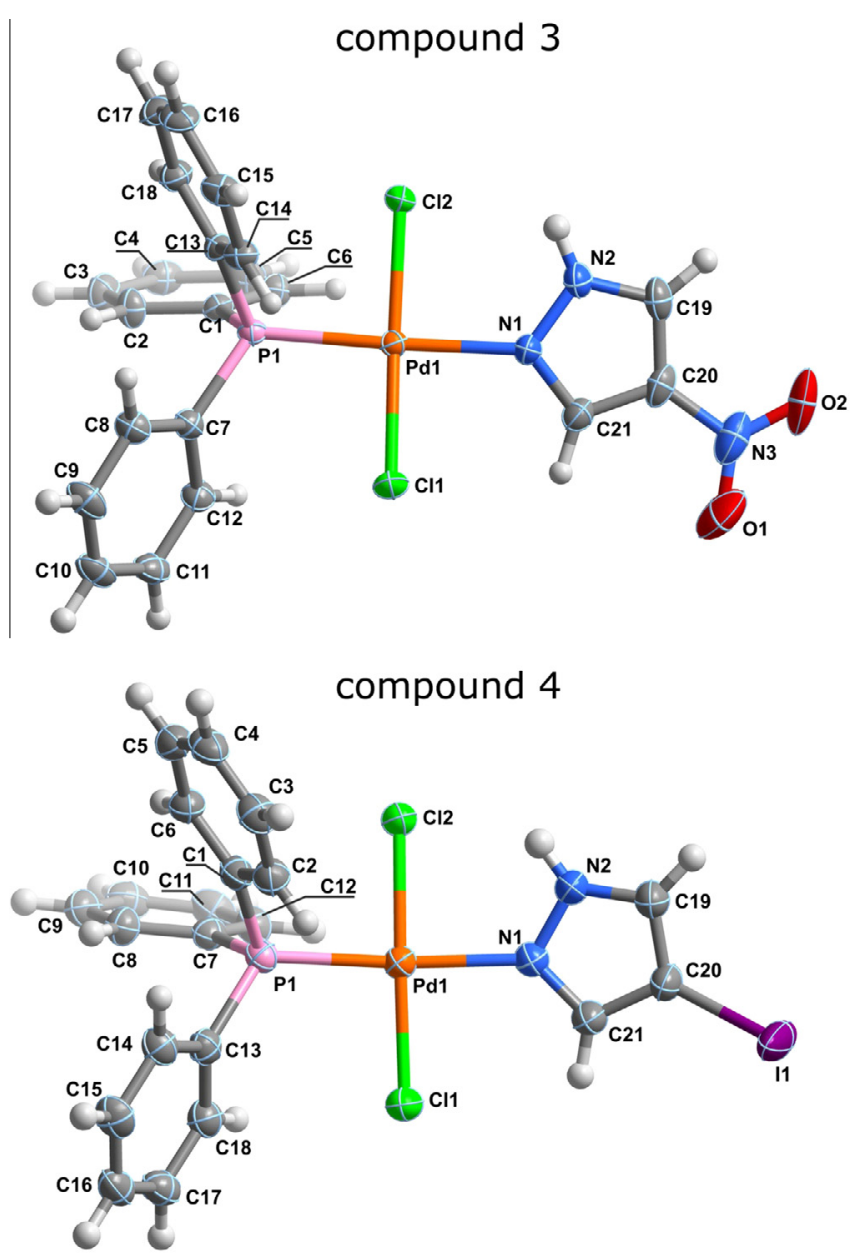

Fig. 1. trans- $\left[\mathrm{PdCl}_{2}\left(\mathrm{HNO}_{2} \mathrm{Pz}\right)\left(\mathrm{PPh}_{3}\right)\right] \cdot 0.9 \mathrm{CHCl}_{3} \quad\left(3 \cdot 0.9 \mathrm{CHCl}_{3}\right)$ and trans$\left[\mathrm{PdCl}_{2}(\mathrm{HIPz})\left(\mathrm{PPh}_{3}\right)\right](4)$ coordination complexes showing non-hydrogen atoms represented as displacement ellipsoids drawn at 50\% probability level and hydrogen atoms as spheres with arbitrary radii. Labels are provided for all non-hydrogen atoms.

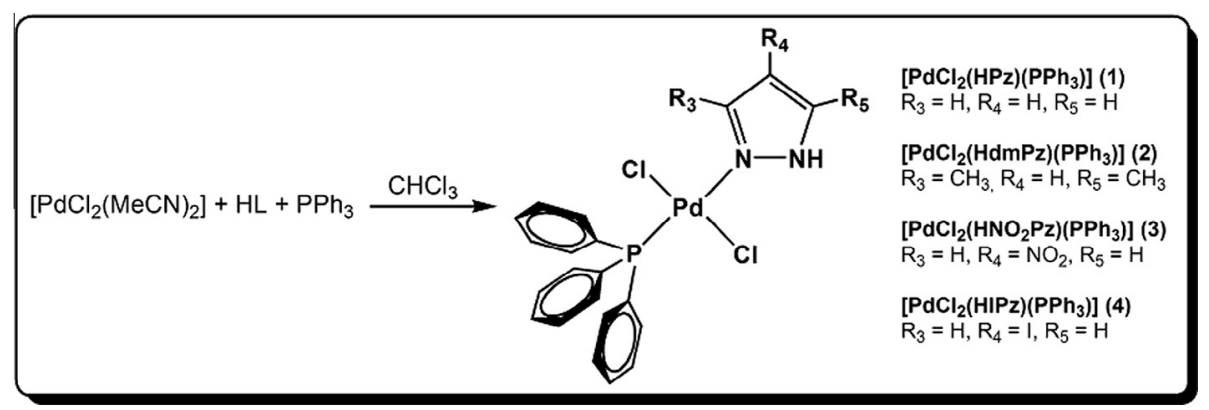

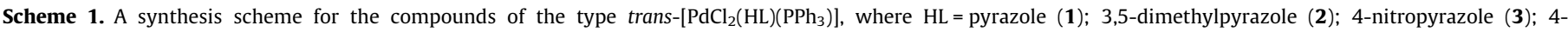
iodopyrazole (4) and $\mathrm{PPh}_{3}=$ triphenylphosphine.

Table 2

Analytical and physico-chemical data on complexes $\left[\mathrm{PdCl}_{2}(\mathrm{HPz})\left(\mathrm{PPh}_{3}\right)\right](\mathbf{1}),\left[\mathrm{PdCl}_{2}\left(\mathrm{HdmPz}_{2}\left(\mathrm{PPh}_{3}\right)\right](\mathbf{2}),\left[\mathrm{PdCl}_{2}\left(\mathrm{HNO}_{2} \mathrm{Pz}\right)\left(\mathrm{PPh}_{3}\right)\right](\mathbf{3})\right.$ and $\left[\mathrm{PdCl}_{2}\left(\mathrm{HIPz}_{(\mathrm{PPh}}\right)\right](\mathbf{4})$.

\begin{tabular}{|c|c|c|c|c|c|c|c|c|}
\hline \multirow[t]{2}{*}{ Complex } & \multirow[t]{2}{*}{$\Lambda_{\mathrm{M}}\left(\Omega^{-1} \mathrm{~cm}^{2} \mathrm{~mol}^{-1}\right)$} & \multirow[t]{2}{*}{ Colour } & \multicolumn{2}{|l|}{ Carbon } & \multicolumn{2}{|l|}{ Nitrogen } & \multicolumn{2}{|l|}{ Hydrogen } \\
\hline & & & Found (\%) & Calc. (\%) & Found (\%) & Calc. (\%) & Found (\%) & Calc. (\%) \\
\hline $\mathrm{C}_{21} \mathrm{H}_{19} \mathrm{Cl}_{2} \mathrm{~N}_{2} \mathrm{PPd}(\mathbf{1})$ & 1.64 & Yellow & 49.80 & 49.86 & 5.50 & 5.52 & 3.82 & 3.77 \\
\hline $\mathrm{C}_{23} \mathrm{H}_{23} \mathrm{Cl}_{2} \mathrm{~N}_{2} \mathrm{PPd}(\mathbf{2})$ & 2.24 & Yellow orange & 52.00 & 51.56 & 5.40 & 5.23 & 4.53 & 5.10 \\
\hline $\mathrm{C}_{21} \mathrm{H}_{18} \mathrm{Cl}_{2} \mathrm{~N}_{3} \mathrm{O}_{2} \mathrm{PPd}(\mathbf{3})$ & 4.59 & Orange & 45.28 & 45.64 & 7.70 & 7.60 & 3.15 & 3.28 \\
\hline $\mathrm{C}_{21} \mathrm{H}_{18} \mathrm{Cl}_{2} \mathrm{IN}_{2} \mathrm{PPd}(\mathbf{4})$ & 4.59 & Light yellow & 39.79 & 39.81 & 4.44 & 4.42 & 2.80 & 2.86 \\
\hline
\end{tabular}


Analytical results are in agreement with the proposed formulae. The molar conductivities of 1-4 in DMSO are between 1.64 and $4.59 \Omega^{-1} \mathrm{~cm}^{2} \mathrm{~mol}^{-1}$, in agreement with their nonelectrolytic nature [36]. These values were significantly lower than those observed for $\mathrm{Pd}(\mathrm{II})$ and $\mathrm{Pt}(\mathrm{II})$ complexes with $1: 1$ electrolyte behaviour $\left(\Lambda_{\mathrm{M}}=20-30 \Omega^{-1} \mathrm{~cm}^{2} \mathrm{~mol}^{-1}\right)$ [37,38]. In addition, the molar conductivity of 1-4 shows little change after storage at room temperature for $24 \mathrm{~h}$ (see Table S1 - Supporting Information), indicating that these species are relatively stable in DMSO solution over a period of $24 \mathrm{~h}$.

\subsection{Single-crystal X-ray diffraction studies}

The monomeric nature and important structural features of $\mathbf{3}$ and 4 were investigated using X-ray diffraction studies. The molecular structures of compounds $\mathbf{3 . 0 . 9} \mathrm{CHCl}_{3}$ and $\mathbf{4}$ are depicted in Fig. 1. Selected bond lengths, bond angles and supramolecular interactions are given in Table 3.

Compound 3 crystallizes in the monoclinic space group $P 2_{1} / c$, with the asymmetric unit being composed by a whole complex molecule and one fraction (0.9) of a chloroform molecule. The metal centre is coordinated to two chloride anions, one molecule of $\mathrm{HNO}_{2} \mathrm{Pz}$ and one $\mathrm{PPh}_{3}$ in a trans configuration, formulated as trans- $\left[\mathrm{PdCl}_{2}\left(\mathrm{HNO}_{2} \mathrm{Pz}\right)\left(\mathrm{PPh}_{3}\right)\right]$ (Fig. 1). The geometry around $\mathrm{Pd}(\mathrm{II})$ is slightly distorted square planar, in which the trans angles, $\mathrm{Cl} 1-$ $\mathrm{Pd}-\mathrm{Cl} 2$ and $\mathrm{N} 1-\mathrm{Pd}-\mathrm{P} 1$, are $176.15(3)^{\circ}$ and $175.32(7)^{\circ}$, respectively; cis angles vary in the interval $87.44(3)-94.19(3)^{\circ}$. The $\mathrm{Pd}-\mathrm{Cl} 2$ bond [2.3004(7) $\AA$ ] is slightly longer than Pd-Cl1 of [2.2794(7) $\AA$ ] and the Pd-N1 bond [2.115(2) $\AA$ ] is higher than those found in regular coordination polyhedron such as $\left[\mathrm{Pd}(\mathrm{SCN})_{2}(\mathrm{HPz})_{2}\right]$, $\left[\mathrm{Pd}(\mathrm{SCN})_{2}(\mathrm{phmPz})_{2}\right] \quad$ (phmPz = 1-phenyl-3-methylpyrazole) [39], $\left[\mathrm{PdCl}_{2}(\mathrm{phmPz})_{2}\right]$ and $\left[\mathrm{Pd}\left(\mathrm{N}_{3}\right)_{2}(\mathrm{phmPz})_{2}\right]$ [40] where $\mathrm{Pd}-\mathrm{N}$ bond was found in the range 2.011-2.018 $\AA$. This difference can presumably be ascribed to the trans effect of the phosphine ligand. The plane of the pyrazole ring and the planar coordination environment around the metal centre are almost co-planar with an interplanar angle of $18.38(13)^{\circ}$.
Compound 4 crystallises in the triclinic space group $P \overline{1}$, comprising an unsolvated complex trans-[ $\left.\mathrm{PdCl}_{2}(\mathrm{HIPz})\left(\mathrm{PPh}_{3}\right)\right]$ with coordination environment around the metal centre similar to that of 3.0.9 $\mathrm{CHCl}_{3}$, with the ligand $\mathrm{HIPz}$ present instead of $\mathrm{HNO}_{2} \mathrm{Pz}$. Conversely, complex $\mathbf{4}$ has a quadratic planar geometry slightly distorted like 3 with trans angles, Cl1-Pd-Cl2 and N1-Pd-P1 of $177.49(5)^{\circ}$ and $174.58(11)^{\circ}$, respectively; the cis angles are found in the range $87.57(5)-94.02(5)^{\circ}$. The $\mathrm{Pd}-\mathrm{Cl} 1 / \mathrm{Cl} 2$ and $\mathrm{Pd}-\mathrm{N} 1$ bonds show the same behaviour as those of complex 3 with bonds distances 2.2792(13)/2.3119(12) $\AA$ and 2.120(4) $\AA$, respectively. The interplanar angle between the plane of the pyrazole ring and the planar coordination environment around the metal centre is $20.0(2)^{\circ}$.

Hydrogen bonding interactions share in the two structures similar features. Both structures show a ring with graph set motif $R_{2}^{2}(4)$ (Fig. 2) formed by the hydrogen bonds interactions between a pair of donors (N2) and a pair of acceptors ( $\mathrm{Cl} 2)$ [32]. This feature is also present in the complex $\left[\mathrm{PdCl}(\mathrm{HPz})\left(\mathrm{C}_{6} \mathrm{H}_{5}\right)\left(\mathrm{PPh}_{3}\right)\right], \mathrm{HPz}=$ pyrazole $)$ [41]. While in 3 the bifurcated $\mathrm{N} 2-\mathrm{H} 2 \mathrm{Z} \cdots(\mathrm{Cl} 2)_{2}$ interaction shows similar D . . A distances and D-H...A angles, in $\mathbf{4}$ the corresponding geometrical parameters are highly unsymmetrical, with a relatively strong intramolecular interaction and a very weak intermolecular interaction (details in Table 2 and Fig. 2). Additionally, the two structures exhibit weak interactions of the type $\mathrm{C}-\mathrm{H} \cdots \pi$. Weak forces of the type $\mathrm{C}-\mathrm{Cl} \cdots \pi$ and $\mathrm{Cl} \cdots \mathrm{I}$ are observed in the crystal structures of 3.0.9 $\mathrm{CHCl}_{3}$ and 4, respectively (details in Table 3).

\subsection{IR spectroscopy}

The FT-IR spectra of 1-4 showed the typical absorptions of coordinated triphenylphosphine at $\sim 748 \mathrm{~cm}^{-1}(\gamma \mathrm{CH}), 1100-1091 \mathrm{~cm}^{-1}$ (q), $\sim 1480 \mathrm{~cm}^{-1}\left(v_{\text {ring }}\right)$ and $\sim 690 \mathrm{~cm}^{-1}\left(\gamma_{\text {ring }}\right)$ [42]. The vibrational modes of $v \mathrm{NH}$ appear at $3324-3175 \mathrm{~cm}^{-1}$ and the displacement of the $v_{\text {ring }}$ band at $1600-1530 \mathrm{~cm}^{-1}$ to $1583-1510 \mathrm{~cm}^{-1}$ suggests that the pyrazoles are coordinated as neutral and monodentate ligands $[23,39,43]$. The most important IR frequencies of the complexes 1-4 along with their assignments are presented in Table 4.

Table 3

Selected geometric parameters $\left(\AA{ }^{\circ}\right.$, for $\left[\mathrm{PdCl}_{2}\left(\mathrm{HNO}_{2} \mathrm{Pz}\right)\left(\mathrm{PPh}_{3}\right)\right]\left(3.0 .9 \mathrm{CHCl}_{3}\right)$ and $\left[\mathrm{PdCl}_{2}(\mathrm{HIPz})\left(\mathrm{PPh}_{3}\right)\right](\mathbf{4})$.

\begin{tabular}{|c|c|c|c|c|}
\hline & $3.0 .9 \mathrm{CHCl}_{3}$ & & 4 & \\
\hline Pd1-N1 & $2.115(2)$ & & $2.120(4)$ & \\
\hline Pd1-P1 & $2.2354(8)$ & & $2.2473(13)$ & \\
\hline $\mathrm{Pd} 1-\mathrm{Cl} 1$ & $2.2794(7)$ & & $2.2792(13)$ & \\
\hline $\mathrm{Pd} 1-\mathrm{Cl} 2$ & $2.3004(7)$ & & $2.3119(12)$ & \\
\hline N1-Pd1-P1 & $175.32(7)$ & & $174.58(11)$ & \\
\hline N1-Pd1-Cl1 & $88.90(7)$ & & $89.81(11)$ & \\
\hline P1-Pd1-Cl1 & $94.19(3)$ & & $94.02(5)$ & \\
\hline $\mathrm{N} 1-\mathrm{Pd} 1-\mathrm{Cl} 2$ & $89.69(7)$ & & $88.74(11)$ & \\
\hline $\mathrm{P} 1-\mathrm{Pd} 1-\mathrm{Cl} 2$ & $87.44(3)$ & & $87.57(5)$ & \\
\hline $\mathrm{Cl} 1-\mathrm{Pd} 1-\mathrm{Cl} 2$ & $176.15(3)$ & & $177.49(5)$ & \\
\hline \multicolumn{5}{|c|}{ Hydrogen bonding interactions } \\
\hline $\mathrm{D}-\mathrm{H} \cdots \mathrm{A}$ & D $\cdots A$ & $<\mathrm{D}-\mathrm{H} \cdots \mathrm{A}$ & $\mathrm{D} \cdots \mathrm{A}$ & $<\mathrm{D}-\mathrm{H} \cdots \mathrm{A}$ \\
\hline $\mathrm{N} 2-\mathrm{H} 2 \mathrm{Z} \cdots \mathrm{Cl} 2$ & $3.082(3)$ & 122 & $3.010(4)$ & 135 \\
\hline $\mathrm{N} 2-\mathrm{H} 2 \mathrm{Z} \cdots \mathrm{Cl} 2^{\mathrm{i}}$ & $3.195(3)$ & 129 & & \\
\hline $\mathrm{N} 2-\mathrm{H} 2 \mathrm{Z} \cdots \mathrm{Cl} 2^{\mathrm{ii}}$ & & & $3.272(5)$ & 109 \\
\hline \multicolumn{5}{|l|}{$C-H \cdots \pi$ contacts } \\
\hline & & C...Cg & & C...Cg \\
\hline & $\mathrm{C} 16-\mathrm{H} 16 \cdots \mathrm{Cg} 2^{\mathrm{iii}}$ & $3.682(3)$ & $\mathrm{C} 2-\mathrm{H} 2 \cdots \mathrm{Cg} 4^{\mathrm{v}}$ & $3.742(7)$ \\
\hline & & & $\mathrm{C} 15-\mathrm{H} 15 \cdots \mathrm{Cg} 1^{\mathrm{v}}$ & $3.759(6)$ \\
\hline & & & $\mathrm{C} 17-\mathrm{H} 17 \cdots \mathrm{Cg}^{\mathrm{vi}}$ & $3.637(6)$ \\
\hline & & & $\mathrm{C} 19-\mathrm{H} 19 \cdots \mathrm{Cg} 2^{\mathrm{vii}}$ & $3.708(6)$ \\
\hline \multicolumn{5}{|l|}{ Other contacts } \\
\hline & $\mathrm{Cl} 3 \cdots \mathrm{Cg} 1^{\mathrm{iv}}$ & $3.3015(16)$ & $\mathrm{Cl} 2 \cdots \mathrm{I} 1^{\mathrm{viii}}$ & $3.7157(16)$ \\
\hline
\end{tabular}

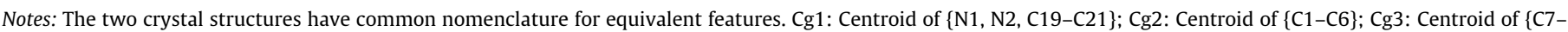

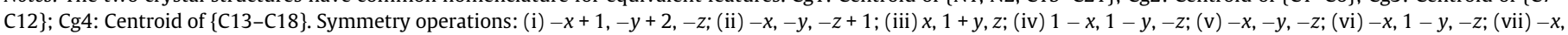
$-y, 1-z$; (viii) $1+x, y, z$. 

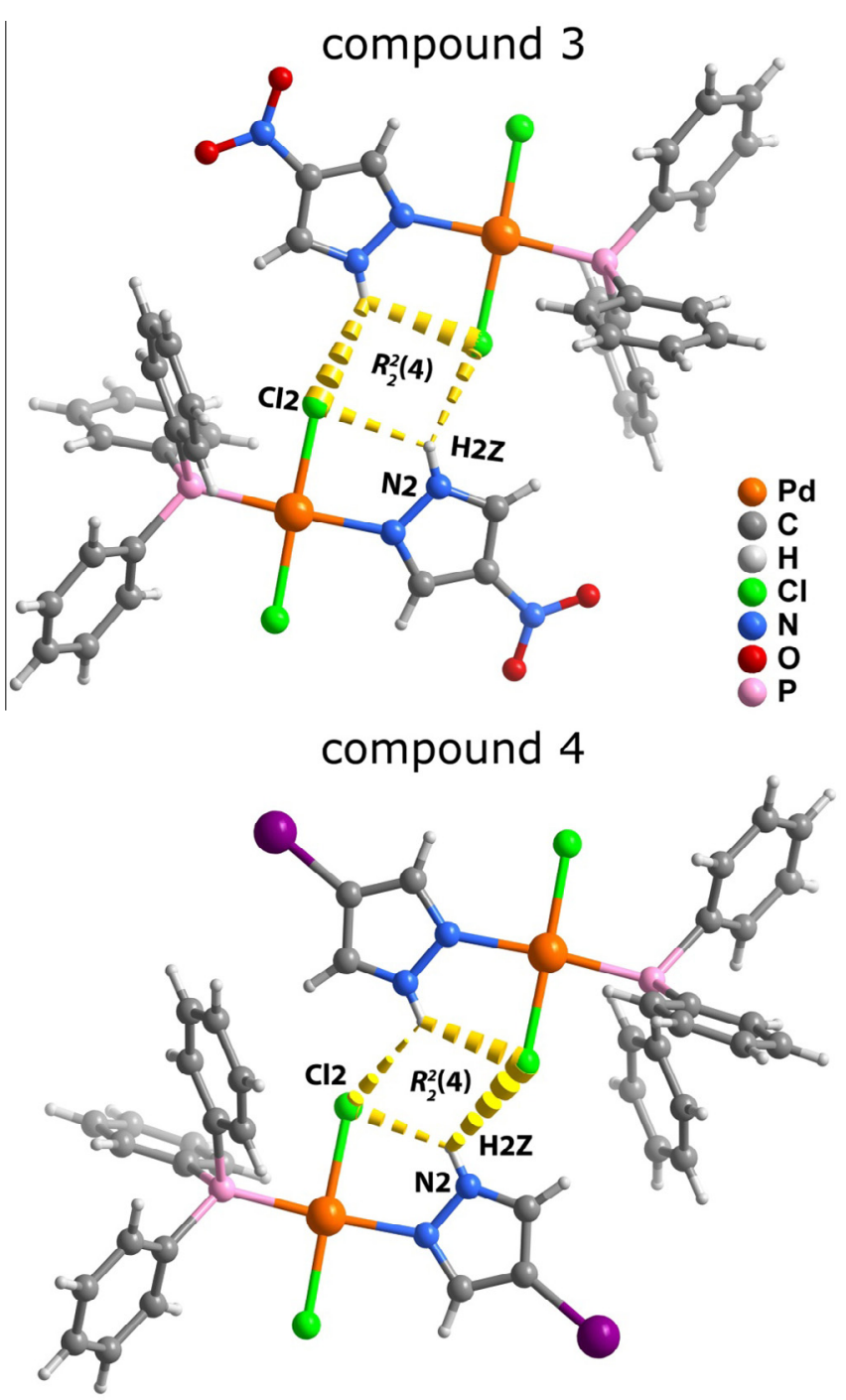

Fig. 2. Supramolecular dimers present in the crystal structures of trans$\left[\mathrm{PdCl}_{2}\left(\mathrm{HNO}_{2} \mathrm{Pz}\right)\left(\mathrm{PPh}_{3}\right)\right] \cdot 0.9 \mathrm{CHCl}_{3}\left(\mathbf{3} \cdot 0.9 \mathrm{CHCl}_{3}\right)$ and trans- $\left[\mathrm{PdCl}_{2}(\mathrm{HIPz})\left(\mathrm{PPh}_{3}\right)\right](4)$. Hydrogen bonds are represented by yellow dashed lines. For details, see Table 3 . (Colour online.)

Compounds $\mathbf{2}$ and $\mathbf{3}$ presented specific vibrational modes related to the pyrazoles substituents. The FT-IR spectra showed the expected $v \mathrm{CH}_{3}$ bands at $2930-2850 \mathrm{~cm}^{-1}$ for the complex 2 and the nitro group at $1550-1520 \mathrm{~cm}^{-1}$ for 3 .

\section{3. ${ }^{1} \mathrm{H}$ NMR spectroscopy}

The ${ }^{1} \mathrm{H}$ NMR results are given in Table 5 . As expected the ${ }^{1} \mathrm{H}$ NMR spectra of compounds 1-4 showed a multiplet attributable to the phenyl groups of the phosphine ligand over the spectral range of 7.89-7.22 ppm. With exception of $2,{ }^{1} \mathrm{H}$ NMR spectra of the complexes exhibited only one set of the expected signals from coordinated pyrazolyl-type ligands, indicating the existence of a single species in solution.

The presence of neutral monodentate pyrazole in $\mathbf{1}$ was substantiated by appearance of the characteristic AMX pattern for the $\mathrm{H}_{3}, \mathrm{H}_{4}$ and $\mathrm{H}_{5}$ atoms of the pyrazole nucleus (see Scheme 1) whereas the monodentate coordination of 4-substituted pyrazoles in $\mathbf{3}$ and $\mathbf{4}$ was evidenced by the appearance of separate singlet resonances for the $\mathrm{H}_{3}$ and $\mathrm{H}_{5}$ atoms [39].

The pyrrolic hydrogen at $\mathrm{N}_{1}$ was detected in all cases by the presence of a broadened singlet at $\sim 12 \mathrm{ppm}$. The ${ }^{1} \mathrm{H}$ NMR spectrum of 2 at room temperature clearly indicated the existence of two conformational isomers in solution, in an intensity ratio of approximately 5:2, by the appearance of two sets of signals for each proton of the coordinated $\mathrm{HdmPz}$ ligand. Such solution behaviour has already been observed in other $\mathrm{Pd}(\mathrm{II})$ compounds bearing 3,5dimethylpyrazole $[44,45]$.

\subsection{Antimycobacterial assays}

In vitro antimycobacterial activities of the ligands, $\left[\mathrm{PdCl}_{2}(\mathrm{MeCN})_{2}\right]$ and the compounds 1-4 were evaluated against the strains of the $M$. tuberculosis $\mathrm{H}_{37} \mathrm{Rv}$ ATCC 27294 [46]. The microplate Alamar Blue assay (MABA) was used to measure the minimal inhibitory concentration (MIC) for the tested compounds (minimum concentration necessary to inhibit 90\% growth of $M$. tuberculosis $\mathrm{H}_{37} \mathrm{Rv}$ ATCC 27294) [46]. The minimum inhibitory concentration (MIC) values are depicted in Table 6.

According to Table 6 , the organic ligands and $\left[\mathrm{PdCl}_{2}(\mathrm{MeCN})_{2}\right]$ precursor displayed no response at compound concentrations $<125 \mu \mathrm{g} \mathrm{mL}^{-1}$ against MTB, and thus have to be considered inactive. However, in most of the cases, simultaneous coordination of pyrazoles and triphenylphosphine on palladium centre resulted in compounds with MIC values ranging from 5.43 to $20.3 \mu \mathrm{M}$. The most active complex was 4 , with a MIC of $7.61 \pm 2.18 \mu \mathrm{M}$. On the other hand, the compound 2 did not inhibit the growth of $M$. tuberculosis, indicating that none of the conformational isomers are active.

From the inspection of MIC values found for complexes 1, 3 and 4, it was noticed a progressive increase on their antimycobacterial activity according to the type of coordinated pyrazolyl ligand $(\mathrm{HL})$, following the order $\mathrm{HNO}_{2} \mathrm{Pz}<\mathrm{HPz} \approx \mathrm{HIPz}$. This finding may suggest that the antimycobacterial effectiveness is dependent, at least in part, on substituent hydrophobicity. Taking into account that $\mathrm{NO}_{2}$ group has a lower contribution to molecular hydrophobicity than $-\mathrm{I}$ and $-\mathrm{H}$ [47], one could roughly speculate that the metalbased derivative containing 4-nitropyrazole (3) possesses decreased lipophilicity. This is evident from the improved activity of 1 and $\mathbf{4}$, compared with the complex 3, presumably because of their relative easiness in crossing the highly impermeable lipid

Table 4

Selected vibrational data $\left(4000-400 \mathrm{~cm}^{-1}\right)$ for the complexes $\left[\mathrm{PdCl}_{2}(\mathrm{HPz})\left(\mathrm{PPh}_{3}\right)\right](\mathbf{1}),\left[\mathrm{PdCl}_{2}(\mathrm{HdmPz})\left(\mathrm{PPh}_{3}\right)\right](\mathbf{2}),\left[\mathrm{PdCl}_{2}\left(\mathrm{HNO} \mathrm{Pz}_{2}\left(\mathrm{PPh}_{3}\right)\right](\mathbf{3})\right.$ and $\left[\mathrm{PdCl} 2(\mathrm{HIPz})\left(\mathrm{PPh}_{3}\right)\right](\mathbf{4})$.

\begin{tabular}{|c|c|c|c|c|}
\hline \multicolumn{4}{|c|}{ Vibrational frequency $\left(\mathrm{cm}^{-1}\right)$} & \multirow[t]{2}{*}{ Assignments } \\
\hline 1 & 2 & 3 & 4 & \\
\hline $3324 \mathrm{~s}$ & $3175 s$ & $3132 \mathrm{~m}$ & 3297 s & $v \mathrm{NH}$ \\
\hline $1515 \mathrm{w}$ & $1579 \mathrm{~m}$ & $1583 \mathrm{w}$ & $1510 \mathrm{w}$ & $v_{\text {ring }}$ \\
\hline $1436 \mathrm{~m}, 1479 \mathrm{w}$ & $1478 \mathrm{~m}, 1435 \mathrm{~s}$ & $1480 \mathrm{~m}$ & $1481 \mathrm{~m}, 1457 \mathrm{~m}, 1431 \mathrm{~m}$ & $v_{\text {anel }}\left(\mathrm{PPh}_{3}\right)$ \\
\hline $1095 \mathrm{~m}$ & $1096 \mathrm{~s}$ & $1100 \mathrm{~m}$ & $1091 \mathrm{~s}$ & $\mathrm{q}\left(\mathrm{PPh}_{3}\right)$ \\
\hline $766 \mathrm{~m}, 748 \mathrm{~m}$ & $748 \mathrm{~s}$ & $749 \mathrm{~s}$ & $747 \mathrm{~m}$ & $\gamma \mathrm{CH}\left(\mathrm{PPh}_{3}\right)$ \\
\hline $690 \mathrm{~s}$ & $692 s$ & $689 \mathrm{~s}$ & $691 \mathrm{~s}$ & $\gamma_{\text {anel }}\left(\mathrm{PPh}_{3}\right)$ \\
\hline
\end{tabular}

$v=$ stretching; $\Phi=$ breathing ring; $\gamma=$ out-of-plane bending; $\mathrm{q}=$ sensitive mode;

$\mathrm{s}=$ strong, $\mathrm{m}=$ medium, $\mathrm{w}=$ weak,. 
Table 5

${ }^{1} \mathrm{H}$ NMR data (ppm) and assignment for complexes 1-4 at $298 \mathrm{~K}$, in $\mathrm{CDCl}_{3}$, given as $\delta\left({ }^{1} \mathrm{H}\right)$, multiplicity [integration].

\begin{tabular}{|c|c|c|c|c|c|}
\hline & & \multicolumn{4}{|l|}{${ }^{1} \mathrm{H}$ NMR } \\
\hline & & 1 & 2 & 3 & 4 \\
\hline \multirow[t]{4}{*}{ Pyrazole ring } & NH & $11.89 \mathrm{~s}[1 \mathrm{H}]$ & $11.70 \mathrm{~s}[1 \mathrm{H}] ; 10.39 \mathrm{~s}[1 \mathrm{H}]$ & $12.47 \mathrm{~s}[1 \mathrm{H}]$ & $12.02 \mathrm{~s}[1 \mathrm{H}]$ \\
\hline & $\mathbf{R}_{3}$ & $8.26 \mathrm{br}[1 \mathrm{H}]$ & $2.67 \mathrm{~s}[3 \mathrm{H}] ; 2.52 \mathrm{~s}[3 \mathrm{H}]$ & $8.87 \mathrm{~s}[1 \mathrm{H}]$ & $8.30 \mathrm{~s}[1 \mathrm{H}]$ \\
\hline & $\mathbf{R}_{4}$ & $6.41 \mathrm{~m}[1 \mathrm{H}]$ & $5.70 \mathrm{~s}[1 \mathrm{H}] ; 5.87 \mathrm{~s}[1 \mathrm{H}]$ & & \\
\hline & $\mathbf{R}_{5}$ & $7.59 \mathrm{br}[1 \mathrm{H}]$ & $1.96 \mathrm{~s}[3 \mathrm{H}] ; 2.22 \mathrm{~s}[3 \mathrm{H}]$ & $8.28 \mathrm{~s}[1 \mathrm{Hs}]$ & $7.66 \mathrm{~s}[1 \mathrm{H}]$ \\
\hline Phenyl ring & $\mathbf{H}$ & $7.83-7.28 \mathrm{~m}$ & $7.88-7.22 \mathrm{~m}$ & $7.70-7.25 \mathrm{~m}$ & $7.89-7.22 \mathrm{~m}$ \\
\hline
\end{tabular}

$\mathrm{s}=$ singlet; $\mathrm{br}=$ broadened $; \mathrm{m}=$ multiplet.

Table 6

MIC values of the ligands, $\left[\mathrm{PdCl}_{2}\left(\mathrm{CH}_{3} \mathrm{CN}\right)_{2}\right]$ and compounds 1-4 against $M$. tuberculosis $\mathrm{H}_{37} \mathrm{Rv}$.

\begin{tabular}{lll}
\hline Compound & MIC & \\
\cline { 2 - 3 } & $\mu \mathrm{g} \mathrm{\textrm {mL } ^ { - 1 }}$ & NHIC \\
\hline Pyrazole $(\mathrm{HPz})$ & $\mathrm{NHIC}$ & \\
3,5-Dimethylpyrazole $(\mathrm{HdmPz})$ & $>250$ & \\
4-Nitropyrazole $\left(\mathrm{HNO}{ }_{2} \mathrm{Pz}\right)$ & $>250$ & \\
4-Iodopyrazole $(\mathrm{HIPz})$ & $>250$ & 481 \\
Triphenylphosphine $\left(\mathrm{PPh}_{3}\right)$ & $>250$ & $11.95 \pm 1.62$ \\
{$\left[\mathrm{PdCl}_{2}\left(\mathrm{CH}_{3} \mathrm{CN}\right)_{2}\right]$} & 125 & \\
{$\left[\mathrm{PdCl}_{2}(\mathrm{HPz})\left(\mathrm{PPh}_{3}\right)\right](\mathbf{1})$} & $6.07 \pm 0.82$ & $18.63 \pm 1.70$ \\
{$\left[\mathrm{PdCl}_{2}(\mathrm{HdmPz})\left(\mathrm{PPh}_{3}\right)\right](\mathbf{2})$} & $>250$ & $7.61 \pm 2.18$ \\
{$\left[\mathrm{PdCl}_{2}\left(\mathrm{HNO} \mathrm{Pz}_{2}\left(\mathrm{PPh}_{3}\right)\right](\mathbf{3})\right.$} & $10.30 \pm 0.94$ & \\
{$\left[\mathrm{PdCl}_{2}(\mathrm{HIPz})\left(\mathrm{PPh}_{3}\right)\right](\mathbf{4})$} & $4.82 \pm 1.38$ & \\
\hline
\end{tabular}

membrane cell wall of TB. Nevertheless, such structure-activity relationship is only preliminary taking into account that they were based on a limited number of Pd(II) compounds. Further experiments on this class of complexes are required in order to rationalize the obtained MIC values in terms of structure-activity relationship as well as to correlate the observed activity with the molecular hydrophobicity of the complexes.

In addition, the incorporation of phosphine-based ligands into the molecular structure of $\mathrm{Pd}(\mathrm{II})$ complexes demonstrated to be an interesting strategy to obtain compounds with in vitro antiproliferative activity against $M$. tuberculosis. The complex 4 ( $\mathrm{MIC}=7.61 \pm 2.18 \mu \mathrm{M}$ ) exhibited a MIC value comparable to those found for $[\mathrm{Pd}(2$-acetylpyridine- $\mathrm{N}(4)$-phenyl-thiosemicarbazone) $\left.\left(\mathrm{PPh}_{3}\right)\right]\left(\mathrm{NO}_{3}\right) \cdot \mathrm{H}_{2} \mathrm{O}, 8.7 \mu \mathrm{M} \quad[48]$ and $[\mathrm{Pd}(\mathrm{C}$-benzylideneaniline $)$ (SCN)(1,3-bis(diphenylphosphino)propane)], $5.15 \mu \mathrm{M}$ [20]. The in vitro activity of $\mathbf{4}$ is also comparable to those observed for some commonly used anti-TB agents (gentamicin, 4.19-8.38 $\mu \mathrm{M}$; tobramycin, 8.56-17.11 $\mu \mathrm{M}$; clarithromycin, $10.70-21.40 \mu \mathrm{M}$ ) [49]. It is important to emphasize that the antimycobacterial studies described here is only the first in a long series of assays that would have to be employed to establish safety and efficacy.

\section{Conclusions}

In conclusion, the new compounds 1-4 were successfully prepared and characterized in this work. The results obtained from in vitro antimycobacterial assays indicated that the enhancement of the hydrophobic character of the substituents in the 4-position on the pyrazole ring results in an increase of the antiproliferative activity $(\mathbf{3}<\mathbf{1} \approx \mathbf{4})$ among the pyrazolyl-based $\mathrm{Pd}(\mathrm{II})$ complexes containing triphenylphosphine as a co-ligand. However, it must be point out that the activity data reported here should not be rigorously interpreted to mean that the structural integrity of complexes is maintained intact during the experiments and the MIC values reproduce precisely the effects of either the $\mathrm{Pd}(\mathrm{II})$ complexes or their products formed from the interaction with the components of the biological media.

\section{Acknowledgements}

This work was sponsored by Grants from FAPESP 2012/154863, CNPq and CAPES. This work was also developed in the scope of the project CICECO-Aveiro Institute of Materials (Ref. FCT UID /CTM /50011/2013), financed by national funds through the FCT/MEC and when applicable co-financed by FEDER under the PT2020 Partnership Agreement. FCT is acknowledge for specific funding of the purchase of the single-crystal X-ray diffractometer. The FCT and the European Social Fund are acknowledged for grant SFRH/BPD/63736/2009 (to JAF).

\section{Appendix A. Supplementary data}

CCDC 1044493 (compound 3.0.9 CHCl3) and 1044494 (compound 4 ) contain the supplementary crystallographic data for this paper. These data can be obtained free of charge via http://www. ccdc.cam.ac.uk/conts/retrieving.html, or from the Cambridge Crystallographic Data Centre, 12 Union Road, Cambridge CB2 1EZ, UK; fax: (+44) 1223-336-033; or e-mail: deposit@ccdc.cam.ac.uk. Supplementary data associated with this article can be found, in the online version, at http://dx.doi.org/10.1016/j.poly.2015.07.009.

\section{References}

[1] <http://www.who.int/tb/publications/global_report/en/index.html>, access: June 27, 2014.

[2] Y.L. Janin, Bioorg. Med. Chem. 15 (2007) 2479.

[3] G.L. Mandell, W.A. Petri Jr., Goodman \& Gilman's The Pharmacological Basis of Therapeutics, 9th ed., McGraw-Hill, New York, 1996, pp. 1155-1174.

[4] F. Ntie-Kang, S. Kannan, K. Wichapong, L.C.O. Owono, W. Sippl, E. Megnassan, Mol. BioSyst. 10 (2014) 223.

[5] D. Castagnolo, A. De Logu, M. Radi, B. Bechi, F. Manetti, M. Magnani, S. Supino, R. Meleddu, L. Chisu, M. Botta, Bioorg. Med. Chem. 16 (2008) 8587.

[6] P.E.A. da Silva, D.F. Ramos, H.G. Bonacorso, A.I. de la Iglesia, M.R. Oliveira, T. Coelho, J. Navarini, H.R. Morbidoni, N. Zanatta, M.A.P. Martins, Int. J. Antimicrob. Agents 32 (2008) 139.

[7] P. Horrocks, M.R. Pickard, H.H. Parekh, S.P. Patel, R.B. Pathak, Org. Biomol. Chem. 11 (2013) 4891.

[8] S. Velaparthi, M. Brunsteiner, R. Uddin, B. Wan, S.G. Franzblau, P.A. Petukhov, J. Med. Chem. 51 (2008) 1999.

[9] M.A. Halcrow, Dalton Trans. (2009) 2059.

[10] J. Pérez, L. Riera, Eur. J. Inorg. Chem. (2009) 4913.

[11] A.V.G. Netto, R.C.G. Frem, A.E. Mauro, Quím. Nova 31 (2008) 1208.

[12] R. Galassi, A. Burini, S. Ricci, M. Pellei, M.P. Rigobello, A. Citta, A. Dolmella, V. Gandin, C. Marzano, Dalton Trans. 41 (2012) 5307.

[13] K. Nomiya, R. Noguchi, K. Ohsawa, K. Tsuda, M. Oda, J. Inorg. Biochem. 78 (2000) 363.

[14] F.V. Rocha, C.V. Barra, A.E. Mauro, I.Z. Carlos, L. Nauton, M. El Ghozzi, A. Gautier, L. Morel, A.V.G. Netto, Eur. J. Inorg. Chem. (2013) 4499.

[15] F.V. Rocha, C.V. Barra, A.V.G. Netto, A.E. Mauro, I.Z. Carlos, R.C.G. Frem, S.R. Ananias, M.B. Quilles, A. Stevanato, M.C. da Rocha, Eur. J. Med. Chem. 45 (2010) 1698.

[16] C.V. Barra, F.V. Rocha, A. Gautier, L. Morel, M.B. Quilles, I.Z. Carlos, O. TreuFilho, R.C.G. Frem, A.E. Mauro, A.V.G. Netto, Polyhedron 65 (2013) 214.

[17] E.T. de Almeida, A.E. Mauro, A.M. Santana, S.R. Ananias, A.V.G. Netto, J.G. Ferreira, R.H.A. Santos, Inorg. Chem. Commun. 10 (2007) 1394.

[18] D.F. Segura, A.V.G. Netto, R.C.G. Frem, A.E. Mauro, P.B. da Silva, J.A. Fernandes, F.A.A. Paz, A.L.T. Dias, N.C. Silva, E.T. de Almeida, M.J. Marques, L. de Almeida, K.F. Alves, F.R. Pavan, P.C. de Souza, H.B. de Barros, C.Q.F. Leite, Polyhedron 79 (2014) 197. 
[19] A.C. Moro, A.C. Urbaczek, E.T. de Almeida, F.R. Pavan, C.Q.F. Leite, A.V.G. Netto, A.E. Mauro, J. Coord. Chem. 65 (2012) 1434.

[20] J.G. Ferreira, A. Stevanato, A.M. Santana, A.E. Mauro, A.V.G. Netto, R.C.G. Frem, F.R. Pavan, C.Q.F. Leite, R.H.A. Santos, Inorg. Chem. Commun. 23 (2012) 63.

[21] C. da Silva, J.G. Ferreira, A.E. Mauro, R.C.G. Frem, R.H.A. Santos, P.B. da Silva, F.R. Pavan, L.B. Marino, C.Q.F. Leite, A.V.G. Netto, Inorg. Chem. Commun. 48 (2014) 153.

[22] A.V.G. Netto, R.C.G. Frem, A.E. Mauro, M.S. Crespi, H.E. Zorel Jr., J. Therm. Anal. Calorim. 87 (2007) 789.

[23] A.V.G. Netto, A.M. Santana, A.E. Mauro, R.C.G. Frem, E.T. de Almeida, M.S. Crespi, H.E. Zorel Jr., J. Therm. Anal. Calorim. 79 (2005) 339.

[24] P.M. Takahashi, A.V.G. Netto, A.E. Mauro, R.C.G. Frem, J. Therm. Anal. Calorim. 79 (2005) 335.

[25] A.M. Bego, R.C.G. Frem, A.V.G. Netto, A.E. Mauro, S.R. Ananias, I.Z. Carlos, M.C. da Rocha, J. Braz. Chem. Soc. 20 (2009) 437.

[26] APEX2, Data Collection Software Version 21-RC13, Bruker AXS, Delft, The Netherlands, 2006.

[27] Cryopad Remote Monitoring and Control, Version 1451, Oxford Cryosystems, Oxford, United Kingdom, 2006.

[28] SAINT+ Data Integration Engine v 723a@ , Bruker AXS, Madison, Wisconsin, USA, 1997-2005.

[29] G.M. Sheldrick, SADABS v201, Bruker/Siemens Area Detector Absorption Correction Program, Bruker AXS, Madison, Wisconsin, USA, 1998.

[30] G.M. Sheldrick, SHELXS-97, Program for Crystal Structure Solution, University of Göttingen, 1997.

[31] G.M. Sheldrick, Acta Crystallogr., Sect. C 71 (2015) 3.

[32] J. Grell, J. Bernstein, G. Tinhofer, Acta Crystallogr., Sect. B 55 (1999) 1030.

[33] J.C. Palomino, A. Martin, M. Camacho, H. Guerra, J. Swings, F. Portaela, Antimicrob. Agents Chemother. 46 (2002) 2720.
[34] S.A. Ahmed, R.M. Gogal, J.E. Walsh, J. Immunol. Methods 170 (1994) 211.

[35] F.R. Pavan, P.I.S. Maia, S.R.A. Leite, V.M. Deflon, A.A. Batista, D.N. Sato, S.G. Franzblau, C.Q.F. Leite, Eur. J. Med. Chem. 45 (2010) 1898.

[36] W.J. Geary, Coord. Chem. Rev. 7 (1971) 81.

[37] B.T. Khan, K. Najmuddin, S. Shamsuddin, S.M. Zakeeruddin, Inorg. Chim. Acta 170 (1990) 129.

[38] B.T. Khan, K. Venkatasubramanian, K. Najmuddin, S. Shamsuddin, S.M. Zakeeruddin, Inorg. Chim. Acta 179 (1991) 117.

[39] A.V.G. Netto, R.C.G. Frem, A.E. Mauro, R.H.A. Santos, J.R. Zoia, Transition Met. Chem. 27 (2002) 279.

[40] A.V.G. Netto, A.E. Mauro, R.C.G. Frem, A.M. Santana, R.H.A. Santos, J.R. Zoia, J Coord. Chem. 54 (2001) 129.

[41] A.J. Canty, W.B. Skelton, A.H. White, Acta Crystallogr., Sect. C C60 (2004) m405.

[42] G.B. Deacon, J.H.S. Green, Spectrochim. Acta 24A (1968) 845.

[43] P.M. Takahashi, R.C.G. Frem, A.V.G. Netto, A.E. Mauro, J.R. Matos, J. Therm. Anal. Calorim. 87 (2007) 797.

[44] A. Boixassa, J. Pons, A. Virgili, X. Solans, M. Font-Bardia, J. Ros, Inorg. Chim. Acta 340 (2002) 49.

[45] V. Montoya, J. Pons, X. Solans, M. Font-Bardia, J. Ros, Inorg. Chim. Acta 358 (2005) 2312.

[46] L.A. Collins, S.G. Franzblau, Antimicrob. Agents Chemother. 41 (1997) 1004.

[47] T.L. Lemke, D.A. Williams, V.F. Roche, S.W. Zito, Foye's Principles of Medicinal Chemistry, 7th ed., Lippincott Williams \& Wilkins, Philadelphia, 2012.

[48] P.I.S. Maia, A. Graminha, F.R. Pavan, C.Q.F. Leite, A.A. Batista, D.F. Back, E.S Lang, J. Ellena, S.S. Lemos, H.S. Salistre-de-Araujo, V.M. Deflon, J. Braz. Chem. Soc. 21 (2010) 1177.

[49] S.G. Franzblau, R.S. Witzig, J.C. McLaughlin, P. Torres, G. Madico, A. Hernandez, M.T. Degnan, M.B. Cook, V.K. Quenzer, R.M. Ferguson, R.H. Gilman, J. Clin. Microbiol. 36 (1998) 362. 